\title{
The Covid-19 Pandemic and the Eurozone: A Reconnaissance of E.U. Financial Assistance to Counteract the Coronavirus's Perfect Storm
}

\author{
Mauro Paoloni ${ }^{1} \&$ Massimiliano Celli $^{1}$ \\ ${ }^{1}$ Department of Business Studies, Roma TRE University, Italy \\ Correspondence: Massimiliano Celli, Department of Business Studies, Roma TRE University, Rome, Via Silvio \\ D’Amico 77, 00145, Italy. E-mail: massimiliano.celli@uniroma3.it
}

Received: February 11, 2021

Accepted: April 26, 2021

Online Published: June 16, 2021

doi:10.5539/ijbm.v16n7p72

URL: https://doi.org/10.5539/ijbm.v16n7p72

\begin{abstract}
As economic scholars and researchers are well aware the Covid-19 pandemic is severely affecting all the European Countries both from a health and economic-productive point of view, and it is not expected to be over before the spring of 2022. In order to counter the effects of this pandemic on the societies and economies of the 27 Member Countries of the EU, the European Institutions (in particular the ECB and the European Commission) have prepared an extensive series of financial assistance instruments, some of which have been developed from scratch while others that already exist have been adequately strengthened. The paper will preliminarily ascertain if Covid-19 was really a "perfect storm", as such absolutely unpredictable, or if it was the consequence of unpreparedness and underestimation. Then the ordinary and extraordinary instruments of financial assistance which the European Institutions have made or will soon make available to the member Countries of the Eurozone to counteract the severe fall in GDP as well as the increase in the unemployment rate, will be investigated. Finally, some conclusions on the topic at stake will be drawn.
\end{abstract}

Keywords: Covid-19 pandemic, Coronavirus, financial assistance, European aid policies

\section{Introduction}

A scientific and objective approach to the study of the socio-economic effects of the Covid-19 pandemic which has been affecting all European Countries for a year now, would require a structured and comparative analysis of data and information whose availability are still excessively partial and fragmentary.

We will therefore limit ourselves to reporting just two aggregate data that are particularly significant in relation to the 27 Members of the European Union at the end (December 31, 2020) of the so-called "phase two" of the health emergency: more than 500.000 deaths and a drop in Eurozone gross domestic product (GDP) of about 8,4\% compared with the same period of the previous year (quantifiable in more than 900,00 billion euros).

Unfortunately, these data are continually getting worse, and what will be the final values at the end of the emergency (maybe in the Spring of 2022) can only be hypothesized with a high margin of error, but to our opinion it is possible to propose since now some considerations on such phenomena.

First of all, it is necessary to verify if Covid-19 is really a "perfect storm", recalled in almost all systemic crises crossed by humanity in the last decades but never fully manifested itself, or if this evocative rhetorical figure is actually a very practical excuse to hide the unpreparedness and underestimation of governments of European Countries.

Then we will analyze the instruments of financial assistance specifically set up by the European institutions to counteract the socio-economic effects of the covid-19 pandemic, in particular the severe fall in European GDP as well as the increase in the unemployment rate, which have never been so severe since the Second World War.

\section{The Covid-19 Pandemic: A Perfect Storm or A Predictable Gale?}

The theory of the perfect storm has been evoked by many to justify the unpredictability of the international financial crisis of 2007 and the subsequent European sovereign debt crisis of 2010 (Paoloni, 2019), but scholars and researchers have now realized that these severe economic phenomena do not present among their own peculiar traits even that of axiomatic imponderability. 
And even before that, the idea of the perfect storm was imagined with regard to the crisis of world financial markets in 1999 caused by the failures of many dot-com companies, and before that in the crisis of Asian markets in 1997 and in those of Japan and Latin America in 1990, just to mention a few, all the way back to the "mother of all perfect storms", the most perfect 1929.

The metaphor of the perfect storm necessarily prefigures a type of event that is unique really, therefore statistically unpredictable given the lack of reliable historical series and whose happening is only hypothetically foreseeable (it is the case, for example, of terrorist attacks on a large scale), and so no analytical-prediction tool can prevent its possible manifestation.

Each banking and financial crisis is certainly characterized by its own peculiarities, but from the crisis of ' 29 of the last century it is in practice always possible to trace known mechanisms and logical sequences that are repeated cyclically in all crises forming cycles of boom and bust. Unfortunately, the premonitory signals of all crises of the last century are almost always ignored by market players in the belief that "this time is different" (Reinhart \& Rogoff, 2009; Tomczak, 2017).

The dramatic collapse of the economies of almost all the industrialized Countries in 2008 (the most ruinous in history after that of 1929, with aggregate losses quantifiable at around 3.400 billion dollars of which 2,800 billion were borne by the credit system - McCauley, Bénétrix, McGuire \& von Peter, 2019), for example, was provoked by the behavior of institutional market players, sometimes motivated by inexperience and/or blind faith in the self-compensatory mechanisms of the markets other times by true predatory instincts (Beutel, List \& von Schweinitz, 2019).

The suggestive thesis of the perfect storm so has proved to be indulgent and self-exculpatory since the determinants of practically all the financial crises that have affected the socio-economic systems of the main industrialized Countries in the last century were easily traceable, in very massive proportions, in the US banking and financial system of 2008 (considered to be at the highest stage of evolution and therefore practically invulnerable), which gave rise to the crisis and whose regulatory mechanisms were unable to prevent either its escalation within national borders or its spread to the rest of the world's economies (McCauley, 2018; Schoen, 2017).

Even in the case of Covid-19, the perfect storm thesis appears to be entirely indulgent and self-exculpatory with respect to almost all Western Countries.

Coronavirus is in fact only the fifth aggressive virus to spread in the last 20 years, although it is the first to be classified in terms of a true pandemic. From 2001 to 2015, there were serious outbreaks of Sars, Avian Influenza, Mers and Ebola (the latter located exclusively in Africa), while numerous and repeated over time were the outbreaks of Yellow Fever and Dengue. These epidemic phenomena have afflicted numerous Countries in Asia (such as South Korea, Singapore, Vietnam and Thailand) and the strategies developed by these Countries to counter them with relative success were equally well known by the international scientific community.

During the Covid-19's outbreak in Europe South Korea itself became a model of efficiency and effectiveness in the fight against the pandemic. The Country was ravaged by the outbreaks of SARS in 2003 and, above all, of the coronavirus MERS (Acute Respiratory Syndrome of the Middle East, with a mortality rate of about 20\%) in 2015 , in the face of which the country-system was caught almost completely unprepared. But the awareness of this unpreparedness as well as the high probability of a new occurrence of similar phenomena, motivated the South Korea's Authorities to elaborate appropriate organizational structures, action strategies, sanitary protocols et al. in order to face future sanitary crises (including the Zika epidemic of 2016, which was an effective "test bench" to validate and refine the above-mentioned prevention and intervention methodologies).

These best practices have been in-depth analyzed by international health institutions, research centers and economic institutes and were emulated to a greater or lesser extent by numerous Countries of Southeast Asia (including a number of Arab Countries concerned about the Ebola outbreaks that recurrently plague the neighboring African continent). Unfortunately, as the chronicles of recent months have relentlessly highlighted, the health systems of all European Countries have not drawn any lessons from the experiences directly lived by those Countries, arriving totally unprepared for the deadly encounter with Covid-19.

The E.U. strategies to contain the pandemic have been far away in effectiveness from those implemented by the Asian Countries mentioned above, whose procedures and protocols were well known to scientific community and whose costs would have been substantially negligible (for example: the implementation of a unique European center for the management and coordination of health emergencies; the activation of adequate IT protocols of contact tracing to perimeter any viral burst; a more adequate training of medical and para-medical 
personnel in concert with the adoption of more streamlined hospital protocols) or disproportionately low compared to the benefits that it could have brought (for example: the constitution of adequate stocks of individual protection instruments for medical personnel and ordinary citizens).

Moreover the availability and proper management of the anti-pandemic tools would not only have made it possible to drastically reduce the very high mortality rate produced by the spread of Covid-19 among the population of all European Countries, but also to achieve this result by minimizing the extent and duration of the recurrent lock-down measures of most productive activities which have unfortunately led to the highest fall in European GDP since the Second World War and an equally dramatic increase in the unemployment rate.

As well demonstrated by South Korea money invested in prevention activities does not only contribute to saving the lives of thousands of people (and this would already be sufficient to justify the outlay) but also allows the creation of new jobs as well as limiting the repercussions on GDP of possible health emergencies. For example, according to recent estimates by the World Health Organization and the World Bank the Sars epidemic in 2003 cost, in terms of loss of global GDP, around 40 billion dollars, while the two strains of Avian Influenza cost around 45 billion dollars and Ebola, which has been claiming victims in Africa for over a five-year period, around 55 billion dollars. Reliable assessments have not yet been produced for Covid-19 pandemic but analysts agree in predicting worldwide losses well in excess of 3,000 billion dollars.

\section{Financial Assistance Guaranteed by European Institutions}

Over the past year, EU Institutions (European Commission and European Central Bank - ECB especially) have strengthened pre-existing financial support programs and developed new emergency programs aimed at providing adequate financial assistance to EU Member Countries affected by the ongoing pandemic. The main assistance programmes are illustrated below, both those of an ordinary nature and those specifically set up to deal with the Covid-19 emergency.

First, a prominent role is undoubtedly played by the European Stability Mechanism (ESM) mutual aid program inaugurated in 2012. This program is a true intergovernmental financial institution with a permanent character and has been modelled on the characteristics of the International Monetary Fund (IMF) as a true rescue-fund (Minenna \& Aversa, 2019; Gros, 2018) with the aim of ensuring the economic and monetary stability of the Eurozone.

This program was included in the institutional architecture of the EU through the amendment of art. 136 of the Treaty on the Functioning of the European Union (TFEU), thus sanctioning the evolution of a European system originally based on the principle of "no bail out" as per art. 125 of the TFEU (the clause that prohibits the ECB from financially supporting the sovereign debt of the Countries of the Eurozone given the conviction that it favors moral hazard) to one based on mutual aid albeit strongly "conditioned" (Ruffert, 2011).

The ordinary budget of the ESM amounts to more than 700 billion euros, of which around 80 billion euros have been progressively contributed by the 27 member Countries of the Eurozone as equity in proportion to the share of the ECB's capital held by each, while the remaining 620 billion euros are raised on the international markets through the issue of fixed/variable rate bonds. The liquid funds that can be used by the ESM to provide financial assistance to Member Countries amount to around 500 billion euros, while the remaining 200 billion euros are statutorily earmarked as reserves to secure the bonds issued (so as to enable the recognition of high ratings for the latter).

The equity and debt capital of the ESM can be used either to directly provide "conditional" loans to the Eurozone Country requesting financial assistance, or to recapitalize banks and financial institutions residing in the Country (Smeets, Jaschke \& Beach, 2019)

The financial assistance granted by ESM to the Countries of the Eurozone is subject to a strict conditionality regime (Bojovic, Munta \& Puetter, 2020) in order to avoid risks of moral hazard. The main conditions that must be met to qualify for financial assistance are: $i$ ) assessment of the extraordinary nature of the Country's crisis by the European Commission and the ECB, as well as verification of the existence of possible risks of contagion to other Countries of the Eurozone; ii) estimation of the Country's real financial requirement; iii) verification of the sustainability of the Country's public debt; iv) ratification of a memorandum of understanding between the beneficiary Country and the ESM, which lists the structural reforms in the fiscal and economic spheres that the Country undertakes to implement within pre-established deadlines in exchange for EU financial assistance; $v$ ) ratification of the European Fiscal Compact by which strict limits on public spending and debt are established.

In May 2020, the European Commission set up a new credit facility equal to around 250 billion euros within the ESM specifically aimed at countering the effects of the Covid-19 pandemic, also removing some of the 
conditions normally envisaged to qualify for financial assistance. The only condition to be observed for the use of such funds is to use them exclusively to fund healthcare costs already sustained and which will be sustained in the near future due to the pandemic, and only for the duration of the emergency period (Camous \& Claeys, 2020). The subsidized credit line is available from June 2020 until the end of 2022 and each EU Country will be entitled to benefit from a 10 -year loan up to a maximum of $2 \%$ of its GDP calculated as of 2019 , at an interest rate of $0.1 \%$.

In any case it is important to highlight that despite the undoubted convenience in purely economic terms, many analysts believe that probably no European Country will have recourse to the ESM (after all as of January 2021 no EU member has yet joined it), since its use could be interpreted as a sign of weakness by international investors and also because the obligation to comply with the aforementioned conditionality clauses is often interpreted as a real cession of sovereignty by the Countries. Besides some Countries (such as France) have even negative yields on ten-year bonds, thus making recourse to the ESM not convenient at all.

The European Central Bank (ECB) plays a complementary role to the ESM programme in providing financial assistance to EU Member Countries and their banking systems. Since the onset of the international financial crisis in 2008 and the subsequently European sovereign debt crisis in 2011, the ECB has not limited itself to carrying out the "canonical" tasks of a Central Bank such as mainly monetary policy interventions, but autonomously implements non-conventional operations to refinance the European credit system and above all to purchase public debt securities of Eurozone Countries considered to be at high risk of financial distress, in order to support the market price and lower the yield.

The ECB's objective is therefore to preserve not only price stability within the Eurozone as prescribed by art. 105 of the Treaty establishing the European Union (TEU) but also, albeit hierarchically subordinate to the former, the economic and financial "health" of the member Countries. The ECB's financial support activity therefore sits alongside, and at times overlaps with, the aforementioned ESM in providing liquidity without time or quantity limits to member Countries and Eurozone banks that request it, asking in return for full compliance with the commitments established in the aforementioned memoranda of understanding. (Note 1).

Among the non-conventional interventions that can be implemented by the ECB to financially support the economic-productive systems of the Countries of the European Union as well as the related banking systems, are:

- $\quad$ The Very Long-Term Refinancing Operations (VLTROs) and the Targeted Longer-Term Refinancing Operations (TLTROs), aimed at providing long-term liquidity to EU banks and financial institutions through the disbursement of loans with a maximum duration of four years with fixed-rate auction procedures (Note 4), receiving as a guarantee from the beneficiaries the securities of the national public debt (Andreeva \& Garcia-Posada, 2021). The aim of the program is obviously to increase the overall supply of credit within the Eurozone, discouraging banks from holding large amounts of liquid funds in reserve and using them instead to purchase sovereign debt securities of European Countries or to finance productive activities. As part of this extraordinary refinancing program for the banking system, in April 2020 the ECB launched a specific project called "PELTRO" (Pandemic Emergency Longer-Term Refinancing Operations) to counter the pandemic emergency and provide further support to the banking and financial system of the Eurozone (Aguilar, Arce \& Hurtado, 2020). This plan consists of seven additional refinancing operations that have begun in May 2020 and will end in a staggered sequence in September 2021 and are conducted via a fixed-rate auction procedure (25 basis points below the average rate of the main refinancing operations).

- The Asset Purchase Programme (APP), which entered its third phase at the beginning of 2019 and is aimed at purchasing on the market not only public debt securities of EU Countries but also private securities, covered bonds and asset-backed securities in order to reduce the existing maturity mismatch between long-term loans (assets) and short-term liabilities (Lewis \& Roth, 2019). In March 2020, the ECB also launched a new temporary program for the purchase of public and private securities concurrent to the APP, in order to counteract the serious risks to which both the transmission mechanisms of monetary policy and the very survival of the Union are exposed due to the effects of Covid-19 on the member Countries. This new program, called Pandemic Emergency Purchase Programme (PEPP), will have a total budget of 1,350 billion euros to be used by June 2021 (which may be increased in size and extended in duration if circumstances require) for the purchase of all categories of assets already admitted under the APP, while at the same time loosening the guarantee requirements.

- The Outright Monetary Transactions (OMT). Following the introduction of the ESM in March 2012 the ECB planned a more articulated policy of purchasing sovereign bonds on the secondary market in order to 
provide conditional financial support to EU Countries. The program consists of discretionary purchases of short-term (1-3 years) sovereign bonds issued by member Countries in financial difficulty to increase their market prices and thus reduce their yield spreads. The activation of the procedure is subject to a strict conditionality criterion based on the signing of a memorandum of understanding agreed upon with the ESM, in which the Country's commitments regarding structural reforms to be implemented are indicated (Note 5). Moreover, the program does not envisage time or quantity limits and the ECB takes care of re-absorbing the liquidity temporarily created at each round of purchases of sovereign debt securities (so-called "sterilization") in order not to increase the monetary base of the euro area, thus avoiding the devaluation of the European currency on the exchange markets (Schoeller, 2018).

- The Quantitative Easing (QE). This program has been launched in 2015 following the example of the Japanese Central Bank in 2001 as well as the US Federal Reserve and the Bank of England in 2008 and will be operational "as long as necessary" as stated by the ECB itself in an official statement. It provides for the long-term and large-scale purchase, from banking counterparties and/or other private institutions, of financial products with extended maturity (government bonds, covered bonds, corporate bonds, asset-backed securities, etc.) for an ordinary amount of 20 billion euros per month in order to support the market price of these assets and thus decrease their yield, as well as to incentivize beneficiary intermediaries to lend the excess liquid funds to households and businesses rather than depositing them with the Central Bank. Unlike other unconventional monetary policy instruments, QE interventions do not include automatic sterilization mechanisms for the greater amounts of money put into circulation, with a consequent increase in the monetary base of the euro area and beneficial effects on the competitiveness of the overall economic-productive system of the Eurozone, given the greater liquidity available to all market players as well as the commensurate depreciation of the EU currency so as to foster exports (Bibow, 2017; Hohberger, Priftis \& Vogel, 2019). To strengthen the ordinary QE program during the Covid-19 crisis, the ordinary budget was increased by a further 120 billion euros for the period April 2020 - December 2021.

In the above-mentioned group of non-conventional intervention instruments currently used by the ECB, there is also the so-called signalling effect. This consists in a communication strategy with which the Central Bank provides market players with forecasts and information on future monetary policy and/or financial assistance programs, in order to condition their current choices. The famous phrase uttered by former Governor Draghi in 2012, regarding the intention to fight recession and deflationary pressures in the Eurozone by any means and at any cost ("Within our mandate, the ECB is ready to do whatever it takes to preserve the Euro, and believe me, it will be enough") can be traced back to this kind of communication strategy (Gifuni, 2019; Ricci, 2015).

In order to assist EU workers, the Eurozone institutions have also launched the SURE programme (Support to mitigate Unemployment Risks in an Emergency). This programme constitutes a sort of temporary redundancy fund aimed at mitigating the consequences of the pandemic crisis on employment, and is a fully-fledged public subsidy that from July 2020 guarantees jobs to the citizens of EU Countries that request it. The financial endowment will be equal to around 100 billion euros (increasable if necessary) raised on international markets through the issue of high rating bonds, against which each member Country will undertake to pay guarantees for an amount proportional to its GDP and up to a total of 25 billion euros (Andor, 2020).

The use of the loan by the Country requesting financial assistance is subject to the prior reaching of a framework agreement between the latter and the European Commission and entails an equivalent increase in domestic public spending. This kind of "European redundancy fund" presents quite favourable conditions for the beneficiary especially if compared with other EU financial assistance programs, while with regard to the actual convenience in terms of interest rates many scholars are rather critical and denounce a negligible saving at the end of the day. Indeed an average saving is estimated in terms of the comparative cost of debt equal to around 0.015 percentage points compared to the issue of national debt securities, which at the same time would not be burdened by the obligation to provide capital as a guarantee as required by SURE.

As regards the financial assistance directly aimed at EU businesses, in April 2020 the European Investment Bank (EIB) set up a guarantee fund of 25 billion euros to be used to guarantee loans granted by EU banks to small and medium-sized enterprises (SMEs) resident in the Eurozone (Note 2), which by virtue of the leverage mechanism will translate into around 200 billion euros in soft and long-term loans. This fund will be financed by the EU Countries on the basis of their share in the EIB's equity capital, while its distribution should take into account only the extent of the damage suffered by the economic-productive system of each Country. With these extraordinary resources the EIB will be able to provide guarantees to Community banks that finance SMEs in the Union as well as to support the Community productive system directly. 
This intervention plan, moreover, comes in addition to the first aid scheme of around 40 billion euros launched by the EIB at the beginning of March 2020 (in addition, of course, to the ordinary activity of the bank), aimed at providing guarantees to credit institutions that provide financial assistance to businesses in crisis as well as liquidity lines to the banks themselves or to take over their "problematic" assets (in particular loans granted to SMEs). A further 5 billion euros are used by the EIB to support investments in the health sector, including hospitals managing the pandemic emergency and pharmaceutical companies.

At the end of the paragraph we have deliberately placed the Community program of financial assistance called Recovery Fund, which, in light of the characteristics proposed by the European Commission on July, 2020 is perhaps the most "attractive" instrument among those just analysed to counter the effects of Covid-19 on the economies of EU member Countries (Bénassy-Quéré \& Weder di Mauro, 2020). The use of conditionality, with regard to any aspect of the instrument under consideration, is, however, quite necessary considering that very few initiatives perpetrated by the Community institutions, since the birth of the European Common Market in 1993, have been the object of such a long and troubled "gestation" characterized by a severe and conflicting negotiation process on the part of Eurozone Countries and the results of which still appear provisional at the moment, both in terms of the amount of financial resources attributable to each Country and the definition of the conditionality regime to be respected in order to benefit from them.

To December 2020 a budget of 750 billion euros has been established for the programme under examination which can be assigned to EU Countries requesting financial assistance from 2021, of which 390 billion euros will be allocated for non-repayable financing (of which 70\% must be committed by 2022 and spent by 2023 , with the remaining $30 \%$ to be spent between 2023 and 2025) and 360 billion for low-interest loans. For the first time in the history of the European Union, these financial resources will be collected through the issue of 30-year bonds by the European Commission directly.

\section{Conclusions}

The sources of EU funding analyzed in the previous paragraph which each European Country is legitimately entitled to apply for, clearly do not deplete the number of instruments that can be utilized to support the national economic-productive apparatus in the extraordinarily severe recessionary phase the Eurozone is experiencing. This is certainly not the right place to analyze further instruments (including, without claiming to be exhaustive: the taking out of subsidized loans by the International Monetary Fund; the taking out of loans with other Countries; the direct intervention of the States in the domestic economic-system) nor to try to identify the most appropriate mix of financial assistance instruments of different source and consistency, but certainly the objective of ensuring the coverage of a financial requirement quantifiable in at least 1.200 billion euros for the whole of 2021 (measured by the loss of GDP expected in the two-year period 2020-2021 compared to 2019) appears not easy to achieve.

We believe, however, that the choices made by the competent decision-making bodies must be free from any political or ideological superstructure and must not become the ground for electoral propaganda, rather being oriented exclusively by the desire to maximize the benefits for each European Country. In this context, clearly, both economic considerations (trivially, the minimization of current and prospective costs associated with each instrument of intervention) and political considerations must be adequately synthesized, meaning a careful and detached evaluation of the conditionalities associated with each instrument of financial assistance.

Above all we are convinced that never before the key to trying to counter the severe recession underway resided in the willingness to negotiate at all levels, not only with regard to potential lenders of liquid funds (first and foremost the Community institutions) but also with regard to the characteristics of the instruments utilized. For example it could be necessary discussing the conditionalities inherent in most Community financial assistance programs in order to temper them or (if possible) temporarily suspend them, or re-discussing the budgetary obligations to which banks are subject in the Community given that their role will be absolutely fundamental in providing liquidity to the European economic-productive system and inevitably the mass of Non-Performing Exposures (of which Non-Performing Loans are the "worst" category - Note 3) that the domestic banking systems will be obliged to hold in the coming years will increase exponentially, thereby thwarting the long and difficult path undertaken over more than a five-year period by credit institutions to bring their balance sheets back into good standing (Ciukaj \& Kil, 2020) through the gradual elimination of large amounts of impaired receivables.

According to the European Banking Authority (EBA), as of December 2020, the value of the Non-Performing Loans (NPL) held by European banks amounted to about 300 billion euros (equal to 3,1\% of the total loans present in the Eurozone banking system). These data, however, have evidently been only marginally affected by 
the serious contraction of economic and productive activities in the EU Countries caused by the Covid-19 pandemic, which is still in progress and which is not expected to be over before spring 2022 (EBA, 2020). Therefore, the Eurozone NPL ratio is expected to increase from 3.1\% to $4.7 \%-5.4 \%$ by end 2021 . This would put between 255-380 billion euros of additional NPLs (2.1-3.2\% of 2020 Eurozone GDP) on EU banks' balance sheets by end 2021. In short the resulting increase in sour loans would offset three years of progress made in reducing the Eurozone NPL ratio from 5.1\% in end 2016 to $3.1 \%$ in end 2019. The deterioration in asset quality amid rising insolvencies would surely push banks to tighten credit conditions in 2021 in Italy, Portugal and Spain, but also in France. Further, deteriorating loan quality is likely to put bank profitability under strong pressure in Germany, Belgium and Portugal.

The hope for all Countries member of European Union is that at this difficult juncture it will be possible to avoid the commission of macroscopic strategic errors, that would then weigh like boulders on the performance of the entire European economic-productive system over a time horizon probably longer than the decade that has just begun.

\section{References}

Aguilar, P., Arce, O., \& Hurtado, S. (2020). The ECB Monetary Policy Response to the Covid-19 Crisis. BancoDeEspana, Documentos Ocasionales.

Andor, L. (2020). SURE - EU Capacity for Stabilising Employment and Incomes in the Pandemic. $Z B W-$ Leibniz Information Centre for Economics, 1-39. https://doi.org/10.1007/s10272-020-0888-y

Andreeva, D. C., \& García-Posada, M. (2021). The impact of the ECB's targeted long-term refinancing operations on banks' lending policies: The role of competition. Journal of Banking \& Finance, 122(1). https://doi.org/10.1016/j.jbankfin.2020.105992

Bénassy-Quéré, A., \& Weder di Mauro, B. (2020). Europe in the Time of Covid-19. London: Centre for Economic Policy Research-CEPR Press.

Beutel, J., List, S., \& von Schweinitz, G. (2019). Does machine learning help us predict banking crises? Journal of Financial Stability, 45(12), 17-43. https://doi.org/10.1016/j.jfs.2019.100693

Bibow, J. (2017). From Anti-Growth Bias to Quantitative Easing: The ECB's Belated Conversion? London: Emerald Publishing Limited.

Bojovic, J., Munta, M., \& Puetter, U. (2020). The European Stability Mechanism and Domestic Preference Formation During the Eurocrisis: The Role of Non-Governmental Actors. Political Studies Review, 18(4), 475-490. https://doi.org/10.1177/1478929919868663

Camous, A., \& Claeys, G. (2020). The evolution of European economic institutions during the COVID-19 crisis. European Policy Analysis, 6(2), 328-342. https://doi.org/10.1002/epa2.1100

Ciukaj, R., \& Kil, K. (2020). Determinants of the non-performing loan ratio in the European Union banking sectors with a high level of impaired loans. Economics and Business Review, 6(20), 22-45. https://doi.org/10.18559/ebr.2020.1.2

European Banking Authority - EBA. (2019). Report on NPLs. Progress made and challenges ahead.

European Commission. (2021). European Business Cycle Indicators - 4th Quarter 2020.

Gifuni, L. (2019). The Financial and Macroeconomic Effects of Security Market Programme, Long Term Refinancing Operation and Outright Monetary Transaction Announcements. Journal of Applied Economic Sciences - JAES, 14(64), 541-563.

Gros, D. (2018). An Evolutionary Path Towards a European Monetary Fund. The Economists' Voice, 15(1). https://doi.org/10.1515/ev-2018-0012

Hohberger, S., Priftis, R., \& Vogel, L. (2019). The macroeconomic effects of quantitative easing in the euro area. Journal of Economic Dynamics and Control, 108(11). https://doi.org/10.1016/j.jedc.2019.103756

Lewis, V., \& Roth, M. (2019). The financial market effects of the ECB's asset purchase programs. Journal of Financial Stability, 43(8), 40-52. https://doi.org/10.1016/j.jfs.2019.05.001

McCauley, R. N. (2018). The 2008 Crisis: Transpacific and Transatlantic? BIS Quarterly Review, 39-58.

McCauley, R. N., Bénétrix, A. S., McGuire, P. M., \& von Peter, G. (2019). Financial deglobalisation in banking? Journal of International Money and Finance, 94(6), 116-131. https://doi.org/10.1016/j.jimonfin.2019.01.011 
Minenna, M., \& Aversa, D. (2019). A Revised European Stability Mechanism to Realize Risk Sharing on Public Debts at Market Conditions and Realign Economic Cycles in the Euro Area. Economic Notes. Review of Banking, Finance and Monetary Economics, 48(1). https://doi.org/10.1111/ecno.12118

Paoloni, M. (2019). La Crisi Finanziaria Nazionale e Internazionale. Giappichelli, Torino.

Reinhart, C. M., \& Rogoff, K.S. (2009). This time is different. Eight centuries of financial folly. Princenton: Princenton University Press.

Ricci, O. (2015). The impact of monetary policy announcements on the stock price of large European banks during the financial crisis. Journal of Banking and Finance, 52(C), 244-255. https://doi.org/10.1016/j.jbankfin.2014.07.001

Ruffert, M. (2011). The European debt crisis and European Union Law. Common Market Law Review, 48(6), 1777-1805.

Schoeller, M. G. (2018). Leadership by Default: The ECB and the Outright Monetary Transactions. Credit and Capital Markets, 51(1), 73-91. https://doi.org/10.3790/ccm.51.1.73

Schoen, E. J. (2017). The 2007-2009 Financial Crisis: An Erosion of Ethics: A Case Study. Journal of Business Ethics, 146, 805-830. https://doi.org/10.1007/s10551-016-3052-7

Smeets, S., Jaschke, A., \& Beach, D. (2019). The Role of the EU Institutions in Establishing the European Stability Mechanism: Institutional Leadership under a Veil of Inter-governmentalism. Journal of Common Market Studies, 57(4), 675-691. https://doi.org/10.1111/jcms.12842

Tomczak, K. (2017). The Impact of the 2007-2008 Financial Crisis on the Banking Systems in Advanced European Countries. Applied Economics Quarterly, 63(2), 161-176. https://doi.org/10.3790/aeq.63.2.161

\section{Notes}

Note 1. In any case, the ECB's scope of action has so far been severely limited by its own statutory provisions, by the disparity of views/objectives among EU member states, by the "no bail out clause" in art. 125 TFEU (which obliges the ECB to provide financial assistance to the countries of the Eurozone exclusively on a conditional basis, in order to limit moral hazard and encourage the adoption of appropriate policies for the consolidation of public accounts), which, although in the last two decades has been subject to a less rigid interpretation and more oriented to the principle of mutual aid, remains one of the cornerstones together with the objective of price stability of the overall work of the ECB, as well as, lastly and perhaps above all, of the European Union's architecture itself (in terms of lack of fiscal uniformity among member Countries, lack of political unity, etc.).

Note 2. The European Commission defines the following composite dimensional parameters in order to identify minor enterprises deserving financial aid schemes: micro-sized enterprises (number of employees less than 10; turnover less than 2,000,000 euros; total activities less than 2,000,000); small-sized enterprises (number of employees less than 50; turnover less than 10,000,000 euros; total activities less than 10,000,000); medium-sized enterprises (number of employees less than 250; turnover less than 50,000,000 euros; total activities less than 43,000,000).

Note 3. As is well known, Non-Performing Exposures are distinguished on the basis of the different probability of recovering the receivable at maturity: 1) Past-Due, exceeding the credit limits by more than ninety days; 2) probable defaults (Unlikely To Pay - UTP), i.e. exposures with regard to which the bank considers it unlikely that the debtor will be able to fulfil in full without recourse to legal guarantee actions; 3) Non Performing Loans - NPL), i.e. exposures to debtors in a state of insolvency or similar.

\section{Copyrights}

Copyright for this article is retained by the author(s), with first publication rights granted to the journal.

This is an open-access article distributed under the terms and conditions of the Creative Commons Attribution license (http://creativecommons.org/licenses/by/4.0/). 